
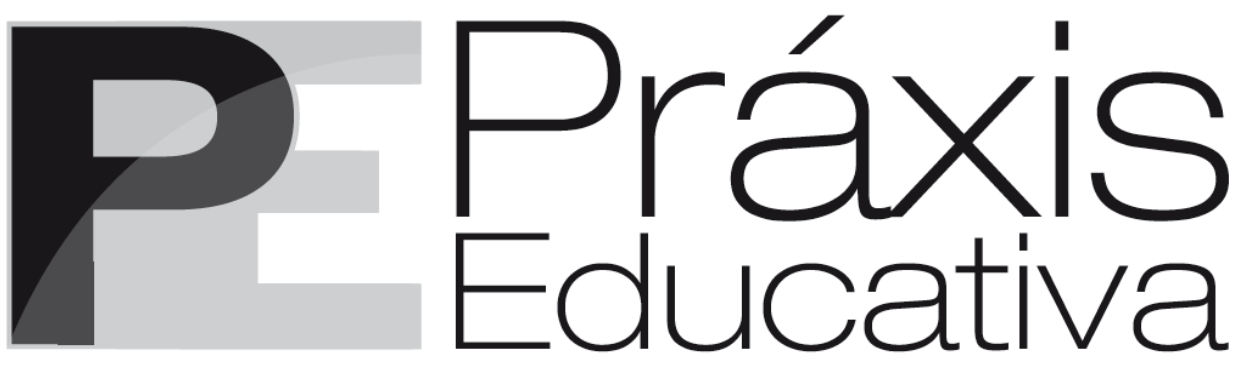

ISSN 1809-4031

elSSN 1809-4309

https://doi.org/10.5212/PraxEduc.v.16.16827.056

\title{
Paulo Freire e os usos da esperança: um relato de experiência
}

\section{Paulo Freire and the uses of hope: an experience report}

\author{
Paulo Freire y los usos de la esperanza: un relato de experiencia \\ India Mara Aparecida Dalavia de Souza Holleben* \\ (iD https:// orcid.org/0000-0003-3756-1103
}

\begin{abstract}
Resumo: Neste texto, afirma-se a atualidade das ideias educacionais nos escritos de Paulo Freire em três de suas obras: Pedagogia do oprimido; Pedagogia da esperanca: um reencontro com a Pedagogia do oprimido; e Pedagogia da indignação: cartas pedagógicas e outros escritos, que são utilizadas como referenciais teóricos para relatar a experiência de ter-se conhecido o educador na Universidade Estadual de Ponta Grossa (UEPG) em 1992. Ao destacar o significado histórico no cenário político daquele momento e do presente, os quais possuem alguns aspectos em comum, revisita-se a concepção de "esperança" que o educador conceitua como imperativo existencial e histórico de estar no mundo e antídoto contra o fatalismo.
\end{abstract}

Palavras-chave: Paulo Freire. Esperança. Práxis.

Abstract: In this text, the topicality of the educational ideas in Paulo Freire's writings is affirmed in three of his works: Pedagogy of the oppressed; Pedagogy of hope: reliving Pedagogy of the oppressed; and Pedagogy of indignation, which are used as theoretical references to report the experience of having met the educator at the State University of Ponta Grossa (UEPG) in 1992. When highlighting the historical meaning in the political scenario of that moment and the present, which have some aspects in common, the conception of "hope" that the educator conceptualizes as an existential and historical imperative of being in the world and an antidote against fatalism is revisited.

Keywords: Paulo Freire. Hope. Praxis.

Resumen: En este texto se afirma la actualidad de las ideas educacionales en los escritos de Paulo Freire en tres de sus obras: Pedagogía del Oprimido; Pedagogía de la Esperanza: un reencuentro con la Pedagogía del Oprimido; y Pedagogía de la Indignación: cartas pedagógicas y otros escritos, que son utilizadas como referencia teórica para relatar la experiencia de haberse conocido al educador en la Universidad Estadual de Ponta Grossa (UEPG), en 1992. Al destacar el significado histórico en el escenario político de aquel momento y del presente, que poseen algunos aspectos en común, se hace revisión de la concepción de "esperanza" que el educador presenta como imperativo existencial e histórico y antídoto contra el fatalismo.

Palabras clave: Paulo Freire. Esperanza. Praxis.

\footnotetext{
* Professora Pedagoga da Rede Estadual de Ensino no Instituto de Educação Prof. César Prieto Martinez - Ensino Fundamental, Médio e Profissional. Mestre em História pela Universidade Federal Fluminense (UFF). E-mail: <profindia@yahoo.com.br>.
} 


\section{Em tempos difíceis é preciso luta e esperança}

Escolhi a sombra desta árvore para repousar do muito que farei, enquanto esperarei por ti.

Quem espera na pura espera vive um tempo de espera vã. Por isto, enquanto te espero trabalharei os campos e conversarei com os homens.

Suarei meu corpo, que o sol queimará, minhas mãos ficarão calejadas, meus pés aprenderão o mistério dos caminhos, meus ouvidos ouvirão mais, meus olhos verão o que antes não viam, enquanto esperarei por ti.

Não te esperarei na pura espera porque o meu tempo de espera é um tempo de quefazer.

Desconfiarei daqueles que virão dizer-me, em voz baixa e precavidos: É perigoso agir É perigoso falar É perigoso andar

É perigoso, esperar, na forma em que esperas, porque esses recusam a alegria de tua chegada. Desconfiarei também daqueles que virão dizer-me, com palavras fáceis, que já chegaste, porque esses, ao anunciar-te ingenuamente, antes te denunciam.

Estarei preparando a tua chegada como o jardineiro prepara o jardim para a rosa que se abrirá na primavera. Paulo Freire (2000a, p. 6).

Canção óbvia foi escrita por Paulo Freire em 1971, quando voltava de Persépolis, no Irã, onde foi receber um prêmio da Organização das Nações Unidas para a Educação, a Ciência e a Cultura (UNESCO) por sua contribuição à Alfabetização de Adultos, em um Seminário sobre Alfabetização. No momento de receber o prêmio, Mario Henrique Simonsen, diretor do Movimento Brasileiro de Alfabetização (MOBRAL), que representava oficialmente o Brasil no evento, retirou-se do recinto em sinal de protesto, deixando o educador entristecido com tamanha incivilidade e deselegância. Esse episódio foi relatado por Francisco Gutiérrez com o título "Caminhante da Obviedade" e faz parte do livro Paulo Freire, uma biobibliografia, de 1996, organizado por Moacir Gadotti e outros autores.

Escrever sobre Paulo Freire no ano em que se comemora o centenário de sua vida e sobre o tema esperança foi uma tarefa duplamente desafiadora, por várias razões. Uma delas foi colocarme diante de uma dúvida: escrever sobre esse grande educador, que foi e tem sido tema de milhares de livros, textos, projetos etc., os quais compõem uma vasta e qualificada produção sobre ele, não seria apenas mais um texto? A outra: falar sobre esperança não pareceria pueril quando temos vivido um dos piores momentos de nossa história, em razão da pandemia do Coronavírus que assola nosso país e o mundo?

Entretanto, bem ao gosto de Paulo Freire, foi "mesmo" na esperança, expressa no poema Canção Óbvia, que fui buscar inspiração para desenvolver a escrita deste texto. Não há dúvidas que, de um lado, há uma sensação de insegurança, de incertezas, de uma ameaça real em nossas vidas, que não deixa nos iludir; por outro lado, não podemos sucumbir ao derrotismo. Em toda sua obra 
e militância, Paulo Freire, insistentemente ao sustentar o chamado à luta, referia-se à impossibilidade de ficarmos de braços cruzados e enfrentarmos com luta a realidade que não é inexorável.

Paulo Freire, pernambucano de Jaboatão, conhecedor profundo do Brasil, em seus intensos 76 anos de vida e trabalho, dedicou-se a mover as comunidades, a educar o povo, abordando a educação como projeto político e a luta coletiva como instrumento de transformação social. Doutor Honoris Causa de inúmeras universidades espalhadas pelos cinco continentes, é o escritor da terceira obra mais citada nas ciências sociais em todo o mundo, a Pedagogia do oprimido, de 1975. Com ela, Paulo Freire reconheceu o pobre e o oprimido como sujeitos da história, e sua teoria passou a ser lida como uma espécie de contra-narrativa ao discurso homogeneizador dos ricos, privilegiados, dominadores, poderosos.

Em 2012, o governo Dilma Rousseff outorgou a Paulo Freire o título de Patrono da Educação Brasileira ${ }^{1}$, por reconhecimento ao mérito de sua obra e às suas principais contribuições para a educação e para a alfabetização no Brasil e no mundo. Contraditoriamente, em maio de 2019, a deputada federal catarinense Caroline de Toni, do Partido Social Liberal (PSL), protocolou um projeto de lei que retiraria de Paulo Freire o título de Patrono da Educação Brasileira, sob a alegação de que seu projeto de educação preocupou-se tão somente em discutir formação política e relegou a segundo plano os verdadeiros desafios da educação.

As considerações introdutórias sobre o autor, sua obra e sua vida, feitas anteriormente, são breves, justamente porque a pretensão deste texto não é se deter especialmente na discussão desses aspectos, mas trazer para o diálogo o tema da esperança, a partir de algumas de suas obras. Além disso, intercalar a esse debate o relato da experiência de tê-lo conhecido na Universidade Estadual de Ponta Grossa (UEPG), na I Jornada de Educação de Adultos, em setembro de 1992.

O relato mencionado é antecedido por um breve panorama do Brasil de 1992 e por uma enxuta contextualização do atual momento, pois considero que há alguma similaridade entre eles, principalmente em relação aos seus aspectos políticos. Ao considerar importante fazer alguns excertos do tema esperança nas Conferências feitas por Paulo Freire na ocasião, pontuo-as no texto, como também abordo como os jornais locais noticiaram sua vinda à cidade e à UEPG.

Apresento, então, ao longo do texto, os apontamentos que Paulo Freire faz sobre a esperança em três de suas obras: Pedagogia do oprimido; Pedagogia da esperança: um reencontro com a Pedagogia do oprimido; e Pedagogia da indignação: cartas pedagógicas e outros escritos. Finalizo o texto reverenciando sua memória e sua obra, bem como sua contribuição ao mundo e ao nosso país.

\section{O andarilho da esperança}

Tratar o tema esperança e seus usos em algumas obras de Paulo Freire desafia-nos ao diálogo e à reflexão e remete-nos a um conjunto de afetos, nesse momento em que "o sentido literal da pandemia é o medo caótico generalizado e a morte sem fronteiras causados por um inimigo invisível" (SANTOS, 2021, p.29) nos mostrando "com uma clarividência nunca vista antes, o pior do mundo em que temos vivido desde o século XVI” (SANTOS, 2021, p.17).

Quando tivemos as primeiras informações sobre o novo Coronavírus, ainda no final de 2019, anunciadas em Wuhan, na China - naquele momento o epicentro da infeção -, não poderíamos imaginar a situação que viveríamos. De Wuhan, o surto epidêmico do novo

\footnotetext{
${ }^{1}$ Lei No 12.612, 13 de abril de 2012 (BRASIL, 2012).
} 
coronavírus, batizado como Sars-CoV-2, rapidamente se espalhou e a Organização Mundial da Saúde (OMS), em março de 2020, reconheceu-o oficialmente como pandemia.

Entre nós, o primeiro caso de coronavírus foi confirmado em 26 de fevereiro de 2020. Desde então, os números cresceram assustadoramente e já foram contabilizados, até a data em que escrevo este texto, o contingente de mais de dez milhões de casos e $378.003^{2}$ mortes no Brasil. Nesse cenário, em que nosso país é destaque internacional e desponta nas primeiras colocações em vítimas pela Covid-19 e é responsável pela criação de novas cepas, o combate à pandemia tem tido resultados desastrosos, entre os quais o colapso do sistema de saúde em praticamente todo o território nacional.

As razões para esses resultados são consequência da fragmentação das políticas estimuladas pelo próprio Governo Federal, a qual desorganizou as medidas essenciais de testagem, de distanciamento social, a compra e a distribuição de vacinas, em uma total ausência de estratégia e de coordenação do Ministério da Saúde, cujo comando foi assumido por um novo ministro pela quarta vez.

Boaventura Souza Santos (2021) afirma que o mundo, desde a década de 1980, tem vivido em permanente estado de crise, na medida em que "[...] o neoliberalismo foi se impondo como a versão dominante do capitalismo e se sujeitando mais e mais à lógica do setor financeiro" (SANTOS, 2021, p. 25). O autor defende a ideia de que "[...] a pandemia veio apenas agravar uma situação de crise a que a população mundial tem estado sujeita” (SANTOS, 2021, p. 25), por isso o imenso e peculiar perigo que ela contém, significa, é.

No caso brasileiro, a luta travada para sair de estados de crise não tem sido esporádica, mas permanente. Pinheiro-Machado (2019) afirma que, desde os acontecimentos de $2013^{3}$, nos sentimos como "[...] em um trem desgovernado por causa de transformações profundas que o Brasil sofreu nos últimos anos, sem saber como dar sentido, viver e combater o caos diário" (PINHEIRO-MACHADO, 2019, p. 11).

Por essas razões, trazer os escritos de Paulo Freire sobre esperança - no centenário de seu nascimento - justamente em um mundo em que se move em uma espécie de caos, convoca-nos não apenas à reflexão, mas à ação. Ação que deve estar comprometida contra o silenciamento, contra as desigualdades, contra as injustiças sociais, contra o desamparo, instaurado por uma "sociologia das ausências", como nomeia Santos (2021, p. 28).

Ao sustentar o argumento de que não podia entender "[...] a existência humana e a necessária luta para fazê-la melhor, sem esperança e sonho" (FREIRE, P., 2001, p. 10), Paulo Freire afirmava "[...]minha esperança é necessária, mas não é suficiente" (FREIRE, P., 2001, p. 10) e "[...] enquanto necessidade ontológica a esperança precisa da prática para tornar-se concretude histórica" (FREIRE, P., 2001, p. 11), asseverando

[...] o exercício da vontade, da decisão, da resistência, da escolha; o papel das emoções, dos sentimentos, dos desejos, dos limites; a importância da consciência na história; o sentido ético da presença humana no mundo, a compreensão da história como

\footnotetext{
${ }^{2}$ Dados do Conselho Nacional de Secretários de Saúde (CONASS) e do Ministério da Saúde em 20 de abril de 2021.

${ }^{3}$ Uma série de protestos que reuniu pautas contra a deterioração do transporte público, a corrupção e os abusos da Copa do Mundo, que se iniciou em abril de 2013, em Porto Alegre, e chegou, em junho, a São Paulo, propagando-se feito um vírus a todas as capitais, às periferias e aos subúrbios do país. Logo, a luta pelos transportes foi contaminada por um sem-número de protestos e, em particular, pelas mobilizações contra os megaeventos, transformando cada partida da Copa das Confederações em massivas manifestações de protesto (ver PINHEIRO-MACHADO, 2019; CAVA; COCO, 2014).
}

Práxis Educativa, Ponta Grossa, v. 16, e2116827, p. 1-18, 2021 
possibilidade, jamais com determinação, é substantivamente esperançosa e, por isso mesmo, provocadora da esperança. (FREIRE, 2000b, p. 48).

Paulo Freire não presenciou historicamente como argumentou em suas obras, um Brasil presidido - em duas gestões consecutivas - por um legítimo representante da classe trabalhadora, Luiz Inácio Lula da Silva, do Partido dos Trabalhadores (PT), partido que o educador ajudou a fundar em 1980. Estas gestões propiciaram significativas melhorias para o povo não há dúvidas, entretanto, como aborda Souza (2019), "[...] o próprio fato de, nos governos do Partido dos Trabalhadores, dezenas de milhões de marginalizados terem a experiência do acesso à educação superior e ao consumo de massa, além de expansão de direitos para negros, mulheres e gays causou violenta reação autoritária [...] por parte da elite e da alta classe média, evidenciada pelo desprezo e pelo ódio ao pobre [...]" (SOUZA, 2019, p. 254).

Da mesma forma, o educador não viu nosso país governado por uma mulher, Dilma Rousseff, a primeira presidenta do Brasil. Ele que, sobre a condição feminina em uma sociedade machista, na obra Pedagogia da esperança: um reencontro com a Pedagogia do oprimido, de 1992, reconhece a linguagem machista com que a escreveu. Paulo Freire conta sobre as cartas que recebeu de inúmeras mulheres que denunciavam a contradição em sua escrita. Mesmo que, na discussão da opressão, da libertação, ele criticava "[...] com justa indignação [as] estruturas opressoras, usava, porém, uma linguagem machista, portanto, discriminatória, em que não havia lugar para as mulheres" (FREIRE, P., 2001, p. 66).

Certamente, Paulo Freire reconheceria a dignidade e a integridade de Dilma nos enfrentamentos que fez para chegar à presidência, além da "[...] condição feminina numa sociedade machista, a militância na clandestinidade, a tortura, a cadeia, a luta tantas vezes ásperas pela democracia, o desafio de participar do primeiro governo dirigido por um trabalhador no Brasil, a superação de um câncer [...]" (AMARAL, 2011, p. 304), até duas campanhas eleitorais duríssimas e duas vitórias. Por fim, enfrentou bravamente o impeachment que a destituiu do cargo de Presidenta da República.

A situação em que se deu o impeachment da presidenta Dilma Rousseff foi marcada por tensões de uma crise política já em andamento, que se avolumou e se expandiu pela sociedade como um todo. Fernandes (2019, p. 112) afirma que "[...] sintomas mórbidos da conjuntura, como o golpe de 2016 e o anticomunismo, contribuem para o quadro crítico da sociedade brasileira", alterando a perspectiva política em especial.

Jessé de Souza (2019), em seu livro $A$ elite do atraso, escreveu um posfácio intitulado "Um país em transe: as razões irracionais do fascismo", no qual ele faz uma síntese do movimento que chama de ciclo pós-golpe de 2013-2016, em que diversos acontecimentos compõem um quadro que permitiram a vitória de Jair Bolsonaro. $\mathrm{O}$ autor argumenta que as apostas dessa elite do atraso são indicadores de quão incoerentes são as formas de pensar e de agir de um contingente de mais de cinquenta milhões de brasileiros e brasileiras que o levaram à presidência.

Não há dúvidas de que a atuação lamentável de Jair Bolsonaro, pari passo com os discursos de sua campanha eleitoral, superou qualquer expectativa e é elevada em grau altíssimo em meio à pandemia. Um pouco antes da pandemia, entre tantas atitudes malsucedidas do atual presidente, figuraram insultos, menosprezo e difamação do pensador Paulo Freire, inclusive como já disse, culminando na proposta de retirada de seu título de Patrono da Educação Brasileira.

No final de 2019, uma das situações que teve repercussão mundial foi a fala do próprio presidente Jair Bolsonaro ao tentar explicar por que defendia o encerramento do Programa TV Escola. Além de desqualificar a programação, definindo-a como "totalmente de esquerda", e de ter

Práxis Educativa, Ponta Grossa, v. 16, e2116827, p. 1-18, 2021

Disponível em: <https://www.revistas2.uepg.br/index.php/praxiseducativa> 
como propósito "deseducar" a população, ele ainda se referiu ao educador Paulo Freire como "energúmeno", desferindo ao educador ofensas vis. Como escreve Araújo (2020), esse qualificativo - energúmeno - caberia muito bem e justíssimo àquele que o profere.

Temos ciência de que a ameaça de um futuro adverso é real; entretanto, como assinalou Paulo Freire, é preciso não temermos a problematização do futuro, pois "[...] a compreensão mecanicista da história, seja de esquerda ou de direita, leva necessariamente à morte ou a negação autoritária do sonho, da utopia, da esperança" (FREIRE, 2020, p. 71).

Outra advertência que fazia o educador sobre a ilusória ideia do sonho e da esperança sozinhos, nos leva a acreditar que, apesar de todo o esforço feito pelas gerações que nos antecederam, elas não nos puderam legar todos os desejos realizados, em razão das circunstâncias históricas e/ou até mesmo por incapacidades humanas. No entanto, as utopias cruzam-se e misturam-se em busca de realizações interrompidas. Por isso, revitalizar as forças políticas de resistência e de oposição ao estado de coisas que estão aí é tarefa nossa, e urgente.

\section{Buscando a esperança em Paulo Freire}

Para tratar do tema da esperança, no espaço que este texto possibilita, sirvo-me de três de seus livros para abordar a temática e, também, para situar a experiência de tê-lo conhecido pessoalmente em 1992. São eles: Pedagogia do oprimido, escrito entre 1967 e 1968, com edição no Brasil em 1974; Pedagogia da esperança: um reencontro com a Pedagogia do oprimido, de 1992; e Pedagogia da indignação: cartas pedagógicas e outros escritos, seu último trabalho, editado em 2000.

Como referencial teórico, recorro também a um importante livro sobre o educador, em que figuram comentários, indicações e informações sobre seus textos, seus livros, sua militância, sua vida. Organizado por Gadotti et al. (1996), o livro Paulo Freire: uma biobibliografia é um registro valoroso do que foi a produção teórica e o ativismo político do educador, em quase 800 páginas que conferem a ele importância insuspeita.

Em Pedagogia da esperança, de 1992, escrita especificamente para tratar da esperança, Paulo Freire compreende-a como de natureza ontológica, e já nas primeiras palavras revela as razões para a escrita do livro, dado o contexto político da época ${ }^{4}$. Paulo Freire (2001, p. 10) reconhece que "[...] sem sequer negar a desesperança como algo concreto e sem desconhecer as razões históricas, econômicas e sociais que a explicam, não entendo a existência humana e a necessária luta para fazê-

\footnotetext{
${ }^{4}$ Fernando Collor de Mello, já no início de seu governo, instituiu medidas econômicas drásticas e de grande impacto, a fim de solucionar a grave crise da hiperinflação, como, por exemplo, com salários e preços congelados e depósitos bancários confiscados por um período de 18 meses. A recessão e o agravamento da crise econômica afetaram a popularidade do presidente Collor de Mello, que, consequentemente, foi perdendo apoio parlamentar com o enfraquecimento político de seu governo. Além disso, o governo Collor de Mello passou a ser alvo de denúncias de corrupção. Vários dos ministros e dos assessores do presidente, além de sua própria esposa, a primeira-dama Rosane Collor, foram acusados de desvio de verbas públicas. Uma das denúncias decisivas no processo foi a que fez em maio de 1992, Pedro Collor, irmão do presidente. Após um desentendimento familiar, o irmão denunciou um extenso esquema de corrupção existente no governo, comandado pelo então tesoureiro da campanha presidencial e empresário Paulo César Farias. Pressionado, o Congresso Nacional instalou uma Comissão Parlamentar de Inquérito (CPI), a fim de investigar as denúncias. Em seguida, foi aberto o processo de impeachment. A CPI e o processo de impeachment paralisaram o país por meses. Nas ruas, setores mais organizados da sociedade começaram a se manifestar em favor do afastamento de Collor da presidência. As maiores manifestações foram promovidas pelos estudantes (universitários e secundaristas) que ficaram conhecidos como os "caras-pintadas", por pintarem listras verdes e amarelas. Enfrentando a oposição de parlamentares do Congresso e manifestações de rua cada vez mais expressivas, o governo Collor ficou completamente isolado, política e socialmente. Em uma sessão histórica, em 29 de setembro de 1992, o Congresso Nacional decidiu-se pela aprovação do impeachment do presidente Collor de Mello. Para evitá-lo, o presidente renunciou em 30 de dezembro. Ver Cancian (2013).
}

Práxis Educativa, Ponta Grossa, v. 16, e2116827, p. 1-18, 2021 Disponível em: <https://www.revistas2.uepg.br/index.php/praxiseducativa> 
la melhor, sem esperança e sem sonho". Ele afirma que o livro foi escrito "[...] com raiva, com amor, sem o que não há esperança” (FREIRE, P., 2001, p. 12).

Ao dizer que é esperançoso não por pura teimosia, mas por imperativo existencial e histórico, Paulo Freire afirma:

Não quero dizer, porém, que porque esperançoso, atribuo à minha esperança o poder de transformar a realidade e, assim convencido, parto para o embate sem levar em consideração os dados concretos, materiais, afirmando que minha esperança basta. Minha esperança é necessária, mas não é suficiente. Ela, só, não ganha a luta, mas sem ela a luta fraqueja e titubeia. Precisamos da esperança crítica como o peixe necessita da água despoluída. (FREIRE, P., 2001, p. 12).

A Pedagogia do oprimido, sua obra mais conhecida, traduzida e mundialmente referenciada, é sem dúvida um clássico da história da educação e da Pedagogia, a qual continua a desempenhar um importante papel em debates sobre educação em nosso país e mundo afora.

Henry Giroux (1996, p. 569) refere-se à Pedagogia do oprimido como um "livro para os que cruzam fronteiras", em que o conceito de educação como projeto político rompe com as múltiplas formas de dominação e resulta na ampliação de princípios e práticas da dignidade humana, liberdade e justiça social.

Talvez o poder e o vigor desse texto devam ser buscados aí, na tensão, na poesia e na política que dele fazem um livro para os que cruzam fronteiras, aqueles que leem história como um modo de clamar por poder e identidade, pela reescritura do espaço e da prática de resistência cultural e política. Pedagogia do oprimido representa uma fronteira textual em que a poesia desliza para o dentro da política e a solidariedade se torna uma canção para o presente começada no passado enquanto espera ser ouvida no futuro. (GIROUX, 1996, p. 570).

Inaugurando um novo pensamento sobre o que é educação, o livro Pedagogia do oprimido, na edição do Brasil, em 1974, foi formulado sob as bases da experiência concreta que Paulo Freire desenvolveu em Recife, no ano de 1963, e durante os anos de exílio no Chile. Sua pedagogia, mais do que uma concepção teórica sobre fundamentos, conceitos e métodos educativos, está alicerçada na prática pedagógica que vai sendo produzida e edificada junto aos sujeitos dessa prática: operários, camponeses, trabalhadores rurais, trabalhadores da construção civil etc. A síntese que articula teoria e prática, práxis, originária dessa experiência, está contemplada em toda a obra de Paulo Freire e representa a coerência de como viveu sua vida, de como escreveu e de como educou.

Talvez seja essa uma das razões pelas quais os conceitos centrais e as bases epistemológicas da Pedagogia do oprimido vão sendo reafirmados, reelaborados e reconstruídos em praticamente todas as suas outras obras.

Ao descrever o conceito da pedagogia que inaugura, Paulo Freire caracteriza-a como "humanista e libertadora" e, para realizar-se como práxis, passa por dois momentos distintos:

O primeiro, em que os oprimidos vão desvelando o mundo da opressão e vão comprometendo-se, na práxis, com a sua transformação; o segundo, em que, transformada a realidade opressora, esta pedagogia deixa de ser do oprimido e passa a ser a pedagogia dos homens em processo de permanente libertação. (FREIRE, 2019, p. 57).

Na última parte do livro Pedagogia do oprimido, Paulo Freire explicita sua concepção de práxis. Ele reafirma que “[...] os homens são seres de práxis, seres do quefazer" (FREIRE, 2019, p. 167). Assim, são "[...] seres do quefazer é exatamente porque seu fazer é ação e reflexão. É práxis. É transformação do mundo" (FREIRE, 2019, p. 167). Freire confirma que o "quefazer" não pode reduzir-se ao verbalismo, tampouco ao ativismo, "[...] o quefazer é teoria e prática, ou seja, como

Práxis Educativa, Ponta Grossa, v. 16, e2116827, p. 1-18, 2021

Disponível em: <https://www.revistas2.uepg.br/index.php/praxiseducativa> 
práxis, portanto, com reflexão e ação incidindo sobre as estruturas a serem transformadas" (FREIRE, 2019, p. 168, grifos do autor).

A práxis revolucionária da qual fala - reflexão e ação transformadora da realidade - é concebida a partir do conceito de práxis de base marxista. Ao tomar como ponto de partida para sua análise o modo de produção capitalista, Paulo Freire insere a educação em seus postulados, anunciando de forma inquietante e sensível a educação como mediadora da humanização, da afirmação de homens e de mulheres, no processo de emancipação humana.

Callado (1979), no livro Tempo de Arraes: uma revolução sem violência, fala do "Método Paulo Freire" ${ }^{, 5}$, descreve poeticamente os efeitos de sua aplicação no estado de Pernambuco e aborda a origem popular nos Círculos de Cultura que aconteciam no Movimento de Cultura Popular em Recife de 1962. Callado (1979) confere a Freire valor social e político.

O Sistema Paulo Freire já tem provas suficientes de que alfabetiza adultos em 40 horas, ou mês e meio a dois meses de instrução. $O$ analfabeto, ao contrário da criança, tem montada em si uma complexa máquina de pensar. Em grande parte inútil, rodando no escuro, apanhando noções ao acaso. Mas quando entra ali, pela leitura, o pensamento concatenado, o moinho está pronto a moer. Outra frase iluminada que anotei quando ouvia histórias dos educandos de Paulo Freire foi do camponês que, ao invés de juntar silabas para formar uma palavra, deixou as sílabas independentes e formou a frase: - Tu já lês.

Como se o $t u$ fosse ele próprio, ou melhor, seu ser novo, alfabetizado. (CALLADO, 1979 , p. 150-151, grifos do autor).

Em razão da criação desse seu "método subversivo", Paulo Freire foi preso, exilado e impedido de viver em sua pátria por 16 anos. Ficou inicialmente na Bolívia como refugiado político, depois rumou para o Chile, onde permaneceu por quatro anos e meio, dedicando-se à educação de camponeses adultos.

Partindo do Chile, Paulo Freire andarilhou pelo mundo, onde colocou em prática suas ideias e ganhou reconhecimento mundial, a partir de 1970, quando publicou Pedagogia do oprimido, em espanhol e inglês e, depois, em 1974, no Brasil.

Hoje, passados mais de meio século da sua publicação, com o esboroamento de nossas instituições sociais, que fazem nossa democracia falha, a Pedagogia do oprimido não poderia ser mais atual. Nela, entre tantas contribuições, Paulo Freire acenou para a noção do "inédito viável", designando o "devir", o "ainda-não", a possibilidade ainda inédita de ação, o futuro a construir-se, o projeto a realizar-se, na incansável defesa da mutabilidade da realidade.

Sobre o "inédito viável”, Ana Maria Freire (2001) observa que, como categoria conceitual, foi pouco comentada e estudada; entretanto, é a mais importante da Pedagogia do oprimido, pois "[...] encerra nela toda a crença no sonho possível e na utopia que virá, desde que os que fazem sua história assim o queiram. Esperanças bem próprias de Paulo Freire” (FREIRE, A. M., 2001, p. 205).

Para a compreensão do "inédito viável", Paulo Freire toma como ponto de partida "as situações-limites" a que todos(as) nós estamos sujeitos(as). A superação delas - que não existe fora das relações do homem-mundo - dá-se pelo enfrentamento da realidade. A realidade de que fala

\footnotetext{
5 As aspas em "Método Paulo Freire" e na palavra "método" ao longo do texto foi utilizada justamente para designar que a expressão era bastante questionada por Paulo Freire, que dizia não haver criado um método, mas uma forma diferente e nova de pensar a educação. E não fez isso sozinho. Só pôde criá-la a partir das relações que estabeleceu com seus educandos(as) nas várias experiências que teve com eles(elas) (BRANDÃO, 1981).
}

Práxis Educativa, Ponta Grossa, v. 16, e2116827, p. 1-18, 2021 Disponível em: <https://www.revistas2.uepg.br/index.php/praxiseducativa> 
o educador pode ser transformada quando, historicamente, os sujeitos tomam consciência de si e do mundo. Nesse sentido, para Paulo Freire (2019), as "situações-limites" não são definidoras da história dos oprimidos - como querem os dominadores, opressores -, pelo contrário, estão contidas nelas o "inédito viável" como horizonte para o qual suas ações serão direcionadas.

O ano de 1992 ficou marcado, na história deste país, como o ano do Brasil passado a limpo; foi o ano em que Paulo Freire se dedicou à escrita do livro Pedagogia da esperança: um reencontro com a Pedagogia do oprimido. Ademais, foi pleno o fervilhar das notícias da impressa, dos jornais e de outros meios de comunicação do país e internacionais, que Paulo Freire esteve em nossa cidade, Ponta Grossa. A experiência de tê-lo conhecido pessoalmente, com todas as nuances do momento político em que estávamos, é o que passo a relatar na sequência deste texto.

\section{A experiência de conhecer Paulo Freire}

Macedo (2016) escreve que toda a experiência ocorre em simultaneidade às ideias e aos acontecimentos e, ao referir-se à essa compreensão, parte de duas perspectivas. $\mathrm{Na}$ primeira, o autor afirma que a experiência é inseparável da subjetividade; e na segunda, aponta que ela produz algo como uma "memória incorporada", a qual resulta em um corpo simultaneamente criado e habitado pela experiência.

Afiançam também Daltro e Faria (2019, p. 231) que o relato de experiência como método de pesquisa é "[...] construído pela presença de elementos teóricos, contextuais, históricos, políticos e críticos [...]", que acabam por afetar "[...] a forma de contar e diz sobre quem conta, se constituindo como marca identitária no processo de construção narrativa" (DALTRO; FARIA, 2019, p. 231). Nesse sentido, a experiência de conhecer pessoalmente Paulo Freire, ainda que o instante vivido tenha sido amplamente educativo, genuinamente pedagógico e de intensa significação, não pode ser separado dos primeiros contatos que tive com sua obra, no curso de Pedagogia, em 1987, na UEPG.

Lembro-me que as primeiras leituras foram perturbadoras, no sentido de desestabilizar a forma de pensar a realidade e a educação. Assim, o exercício de rememoração e de releitura de algumas passagens das obras mencionadas reavivou as primeiras descobertas do pensamento de Paulo Freire, e a sensação de que tinha de lê-lo com urgência. Urgência de quem chegou tardiamente a esses saberes, mas que sabia que seriam duradouros e norteadores de meu ofício de educadora. Posteriormente, minha trajetória profissional foi marcada por essa lembrança viva e contundente.

A visita de Paulo Freire à UEPG, nos dias 25 e 26 de setembro de 1992, para palestrar na I Jornada de Educação de Adultos, foi promovida pelo Projeto de Extensão "Redescobrindo o Mundo". Esse Projeto foi idealizado, em 1989, pela professora Carmencita de Holleben Melo Ditzel, do Departamento de História. No projeto inicial, constam como participantes as professoras Cleide Aparecida Faria Rodrigues (Departamento de Educação) e Thereza Cristina Push (Departamento de Letras) (UEPG, 1989). Destinava-se à alfabetização de jovens e adultos e, a princípio, teve como projeto piloto alfabetizar trabalhadores da construção civil que, à época, trabalhavam nas obras do campus de Uvaranas da UEPG. As atividades tiveram início a partir de 1990, ano em que ingressaram no projeto os professores Jefferson Mainardes, do Departamento de Educação, Jussara Ayres Bourguignon (Departamento de Serviço Social) e Roque Zimmerman (Departamento de Educação). Em 1991, com o lançamento do Plano Nacional de Alfabetização e Cidadania, em 1991, foi expandido para vilas e periferias da cidade. Em 1992, o projeto contava com 29 polos de alfabetização, 42 alfabetizadores e 500 alfabetizandos, com formação permanente dos alfabetizadores e assessoria pedagógica e administrativa. Os polos de alfabetização 
funcionavam em escolas, centros comunitários, igrejas, ou em outros locais de fácil acesso aos alfabetizandos. O projeto foi desenvolvido de 1990 a 1998 sob a coordenação dos professores Carmencita de Holleben Mello Ditzel (1990 a 1991) e Jefferson Mainardes (1992 a 1998) (UEPG, 1994, 1998).

Segundo o Professor Jefferson Mainardes (informação verbal) ${ }^{6}$, a ideia de convidar Paulo Freire e Ana Maria Freire para o evento I Jornada de Educação de Jovens e Adultos foi da Professora Jussara Ayres Bourguignon, que atuava no projeto. O projeto fundamentava-se nas ideias de Paulo Freire, e o livro de Ana Maria Freire (1989), Analfabetismo no Brasil, era uma referência importante para o projeto. O convite foi feito em 13 de abril de 1992, e a resposta do aceite ocorreu por meio de carta de 13 de maio do mesmo ano.

A abertura do evento foi realizada pelo Professor Jefferson Mainardes, do Departamento de Educação da UEPG, que evidenciou a alegria e a emoção de toda a comunidade universitária ao receber o ilustre educador e sua esposa Ana Maria na I Jornada de Educação de Jovens e Adultos. Sublinhou também a inspiração de obras de Paulo Freire para a criação e o desenvolvimento do projeto de extensão em questão. Destacou, também, a importância da Conferência de Ana Maria de Araújo Freire, que seria proferida no dia seguinte, dia 26 de setembro com o tema "A questão do Analfabetismo na atual conjuntura brasileira".

O Magnífico Reitor da UEPG, Professor João Carlos Gomes, em seu pronunciamento, acentuou o papel da universidade na formação e no exercício da cidadania, cujos deveres educacionais não podiam ser adiados, dada a fragilidade cultural das expressões políticas daquele momento e, por isso, devia colocar-se à frente das tarefas, entre as quais ele destacou a execução do Projeto de Extensão "Redescobrindo o Mundo".

A Professora Zélia Maria Lopes Marochi, docente do Departamento de Métodos e Técnicas de Educação, da UEPG, e orientanda de Mestrado de Paulo Freire na Pontifícia Universidade Católica de São Paulo (PUC-SP), antes de acompanhá-lo à mesa (Figura 1) para mediar a primeira Conferência realizada na parte da manhã, fez uma importante apresentação da biografia do Professor Paulo Freire, trazendo conhecimentos e informações sobre sua trajetória de vida e sobre suas experiências educacionais no Brasil e no mundo. A Professora Zélia fez uma retrospectiva emocionada das vivências de Paulo Freire, suas lutas, notabilizando, ainda que brevemente, as ideias e os conceitos que moveram seu trabalho de educador e de escritor (MAINARDES, 2021, informação verbal) ${ }^{7}$.

\footnotetext{
${ }^{6}$ Informação fornecida na UEPG, em Ponta Grossa, em março de 2021.

${ }^{7}$ Informação fornecida na UEPG, em Ponta Grossa, em março de 2021.
} 
Figura 1 - Mesa dos trabalhos no Grande Auditório da UEPG (26/09/1992)

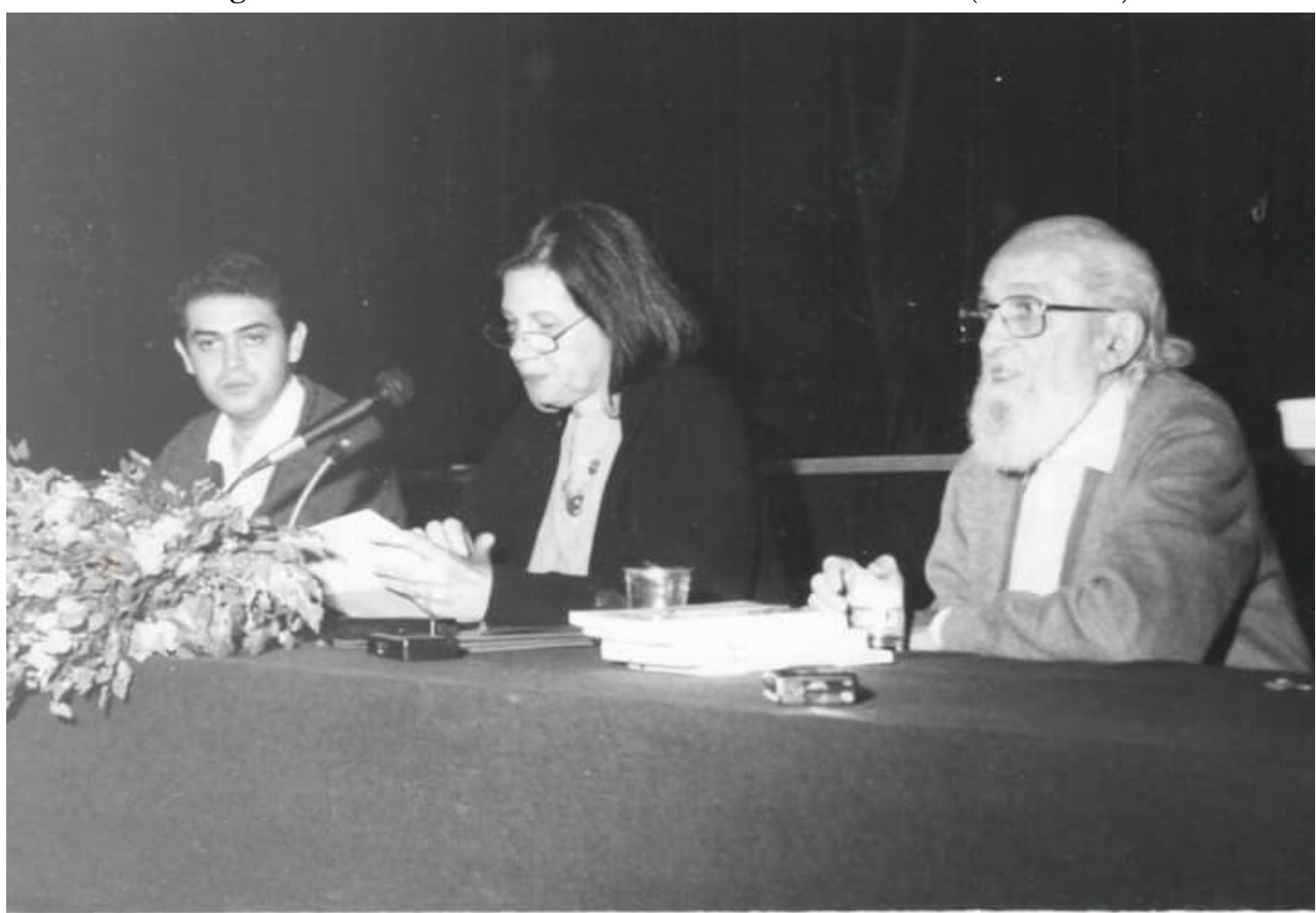

Fonte: Imagem cedida por Jefferson Mainardes.

Obs.: Na mesa dos trabalhos no Grande Auditório da UEPG, em 26 de setembro de 1992, encontra-se Paulo Freire à direita da imagem; à sua esquerda está sua esposa, Ana Maria Araújo Freire, e, à esquerda dela, o Professor Jefferson Mainardes, do Departamento de Educação.

Como é de praxe em suas obras, a escrita das "Primeiras Palavras", Paulo Freire expressouse dessa forma na Conferência de abertura intitulada "Concepções de Educação, Educação de Adultos e Educação Popular”. Na noite de 25 de setembro de 1992, o Grande Auditório da UEPG ficou lotado, inclusive na galeria superior, bem como nos corredores do Bloco A.

Nas "Primeiras Palavras" como sugeriu, Paulo Freire falou da alegria de participar do evento, pois, mesmo adoentado, cansado da viagem e dos exames que a antecederam, ele se sentia revigorado.

Em primeiro lugar, quero agradecer, dizer que nunca é demais para nenhum de nós, nenhuma de nós dizer muito obrigado, ao contrário, o dever de dizer muito obrigado, dizer que esse é um dos deveres que cumpro com muita satisfação, com alegria. Agradecer por ser acolhido e recebido festivamente agora aqui. [...]. Essa quantidade de gente que vem cá por uma real curiosidade é elogiável, porque vem por uma curiosidade não em torno de mim, mas uma curiosidade em torno de um tema, mas que junta essa curiosidade em torno de um certo tema, uma certa expressão afetiva por quem traz o tema. E como sou eu hoje que trago o tema, [...] essas coisas me alegram demais. Essas coisas só não me fazem arrogante, só não me fazem sentir que eu sou um ser diferente, só não me fazem pensar que tenho verdades inatacáveis. [...] sou profundamente gente antes de ser um intelectual razoável, e como sou profundamente gente, e porque sou gente, gosto de ser amado, gosto de ser querido, e gosto de amar. (FREIRE, 1992a, $17 \mathrm{~m} 14 \mathrm{~s})$

Sobre a tarefa que compete à universidade brasileira e ao Terceiro Mundo, uma delas é a de fazer algo que corresponda à maioria das necessidades e dos interesses do povo brasileiro, sem perder a seriedade acadêmica e de pesquisa que lhe são próprias. O educador proferiu:

Práxis Educativa, Ponta Grossa, v. 16, e2116827, p. 1-18, 2021

Disponível em: <https://www.revistas2.uepg.br/index.php/praxiseducativa> 
A universidade deve abrir-se mais ao mundo mesmo que a cerca, é se aproximar da realidade concreta do país em que ela está, a universidade, das dificuldades da sociedade que ela se encontra. [...] uma universidade que se preocupa em ir até as classes populares proibidas de ser, uma universidade que pergunta, que ausculta as classes populares em seu silêncio e lhes pergunta o que querem, como querem, o que pensam, como pensam. A quem diga que fazer isso é diminuir, é minimizar a sua tarefa, mas não é. A universidade pode e deve desenvolver tarefas assim, sem diminuir em nada a seriedade acadêmica e a pesquisa séria que desenvolvem. (FREIRE, 1992a, 22m08s).

Ao manifestar o sentimento de alegria de participar do evento, Paulo Freire afirmou que estar naquele momento ali era um, entre tantos outros motivos, que fez valer a pena viver, de estar no mundo. Ele mencionou, depois desse prelúdio, referindo ao costume já mencionado: “[...] minhas palavras segundas são para felicitar, para parabenizar a Universidade pela ideia de criar um programa assim, cujo próprio nome sugere um mundo de coisas" (FREIRE, 1992a, $21 \mathrm{~m} 04 \mathrm{~s}$ ).

Antes de passar ao tema específico da conferência, Paulo Freire reiterou as felicitações feitas à toda a comunidade universitária pelo evento, ensejando que outros caminhos fossem descobertos para ampliarem a forma de ação, como as desenvolvidas no Projeto de Extensão "Redescobrindo o Mundo".

O educador propôs como metodologia, como já utilizada na palestra "Paulo Freire: 'Dialogando sobre a docência na Universidade"', feita pela manhã, que o público fizesse perguntas dentro do quadro geral do evento. Ao trazerem suas inquietações, críticas e dúvidas, estimulariam seu pensamento e sua preleção sobre o tema. E para dar uma resposta - não a resposta certa -, mas, sim, alguma resposta acerca do que foi perguntado, Freire faria pequenas palestras, pequenas conferências sobre os assuntos abordados nas perguntas. E assim se procedeu.

Nas discussões realizadas pela manhã, na palestra "Paulo Freire: 'Dialogando sobre a docência na Universidade", a partir dos questionamentos feitos pelo público, Paulo Freire abordou vários conceitos, como, por exemplo, a relação dialética entre pesquisa e docência e a importância absoluta de ambas para o desenvolvimento de uma nação. O educador afirmou "[...] não ser possível conceber o desenvolvimento de um país sem docência competente, e sem pesquisa competente" (FREIRE, 1992b, 1h22m29s.)

Sobre a ilusória separação entre docência e pesquisa, Paulo Freire acrescentou a necessidade de incluir a extensão como uma prática inerente às outras duas:

No momento em que se dicotomiza uma coisa da outra, estabelecemos guetos na prática acadêmica. Por isso, docência, pesquisa e extensão, deveriam constituir um tecido interrelacionado dialeticamente, contraditoriamente dentro da universidade, de modo que recebesse bem os grupos populares dentro dela e andasse bem até os grupos populares. (FREIRE, 1992b, 1h33m57s).

Para isso, afirmou Paulo Freire, teríamos de brigar contra algo histórico em nosso país e que acompanha as universidades brasileiras, que é o elitismo de classes, como questão política e ideológica e não como questão pedagógica que impede o acesso desses grupos populares à educação formal, desde a Educação Básica.

No conjunto dos significados e dos entendimentos com os quais ele brindou aquela plateia, o educador fez uma síntese - com a simplicidade própria dos sábios - sobre como ainda deseja ver e viver seu país: "Meu sonho de sociedade é a de vê-la menos injusta do que essa, em que não haja tanta sem-vergonhice quanto hoje no Brasil; uma sociedade cujo respeito à dignidade dos cargos, à dignidade das tarefas; o respeito às pessoas seja uma coisa óbvia, não uma coisa espantosa" (FREIRE, 1992a, 49m30s). 
Em outros momentos de sua fala, Paulo Freire reiteradamente fez referência a questões como a raiva, a fúria que mobiliza "[...] nossos sensos de justiça e nos conclama para a luta", como aparecem em algumas passagens da Pedagogia da indignação cartas pedagógicas e outros escritos:

Tenho o direito de ter raiva, de manifestá-la, de tê-la como motivação para minha briga tal qual tenho o direito de amar, de expressar meu amor ao mundo, de tê-lo como motivação de minha briga, porque histórico, vivo a História como tempo de possibilidade não de determinação [...]. Meu direito à raiva pressupõe que, na experiência histórica da qual participo, o amanhã não é algo "pré-dado", mas um desafio, um problema. A minha raiva, minha justa ira, se funda na minha revolta em face da negação do direito de "ser mais" inscrito na natureza dos seres humanos. (FREIRE, 2000b, p. 78-79).

Durante todo seu tempo de diálogo, Paulo Freire, em nenhum momento, destituiu de rigor científico e crítico os temas abordados; imprimiu bom humor, amabilidade e afeto à dureza das problematizações que pontuava, fertilizando-as com anedotas e recortes de suas histórias vividas com as gentes de todo o mundo.

Fora do âmbito universitário, embora o evento tenha sido suficientemente divulgado, as notícias da imprensa local fizeram poucas considerações sobre o educador, e dois jornais - o Jornal da Manhã e o Diário dos Campos - publicaram reportagens sobre sua estadia em Ponta Grossa.

O Jornal da Manhã realizou com o educador uma entrevista que denominou de "exclusiva", com a chamada "Paulo Freire traça perfil educacional do País". O Diário dos Campos, por sua vez, informou, em primeira página, sobre a presença do educador na universidade: "UEPG traz Paulo Freire para a Jornada da Educação de Adultos".

No Diário dos Campos, a reportagem detalhou a programação do evento e fez uma síntese do pensamento do educador e de sua esposa Ana Maria. Sobre o autor, o jornal declarou:

Idealizador de uma proposta de educação baseada no diálogo entre o educador e educando, Paulo Freire acredita que a educação deva ser um ato solidário e coletivo, enfim, uma relação de troca entre as pessoas. Partindo da realidade das pessoas e de temas surgidos de sua vivência, a proposta de Freire procura auxiliar no desenvolvimento de uma consciência mais crítica, e daí a definição como "Educação Libertadora". Com diversas obras publicadas, Paulo Freire, como filósofo da Educação e humanista, destacase entre as mais ilustres personalidades em Pedagogia. (UEPG..., 1992, n.p.).

Em entrevista dada ao Jornal da Manhã, quando perguntado sobre a situação atual da educação brasileira, Paulo Freire respondeu que toda a situação educacional nunca pode ser percebida e entendida fora da situação geral da própria sociedade. Para o educador:

O Brasil vive hoje, na minha opinião, uma situação última como esperança, quer dizer, num momento em que todas as denúncias que estão sendo feitas contra a corrupção, contra a democratização da sem-vergonhice que se vem fazendo neste país há muito tempo, contra os exageros do despudor, no momento em que se denuncia a imoral forma de governar esse país, onde essas denúncias alcança o próprio Presidente da República que está ensopado de coisas horríveis, nesse momento, quando menos se esperava, a juventude volta às ruas. (PAULO..., 1992, n.p.).

Práxis Educativa, Ponta Grossa, v. 16, e2116827, p. 1-18, 2021

Disponível em: <https://www.revistas2.uepg.br/index.php/praxiseducativa> 
Além da enriquecedora conferência assistida, ainda na noite de 25 de setembro de 1992, participei como convidada do jantar oferecido pela professora Zélia Maria Lopes Marochi, em sua residência para Paulo Freire e sua esposa, Ana Maria Araújo Freire (Figura 2).

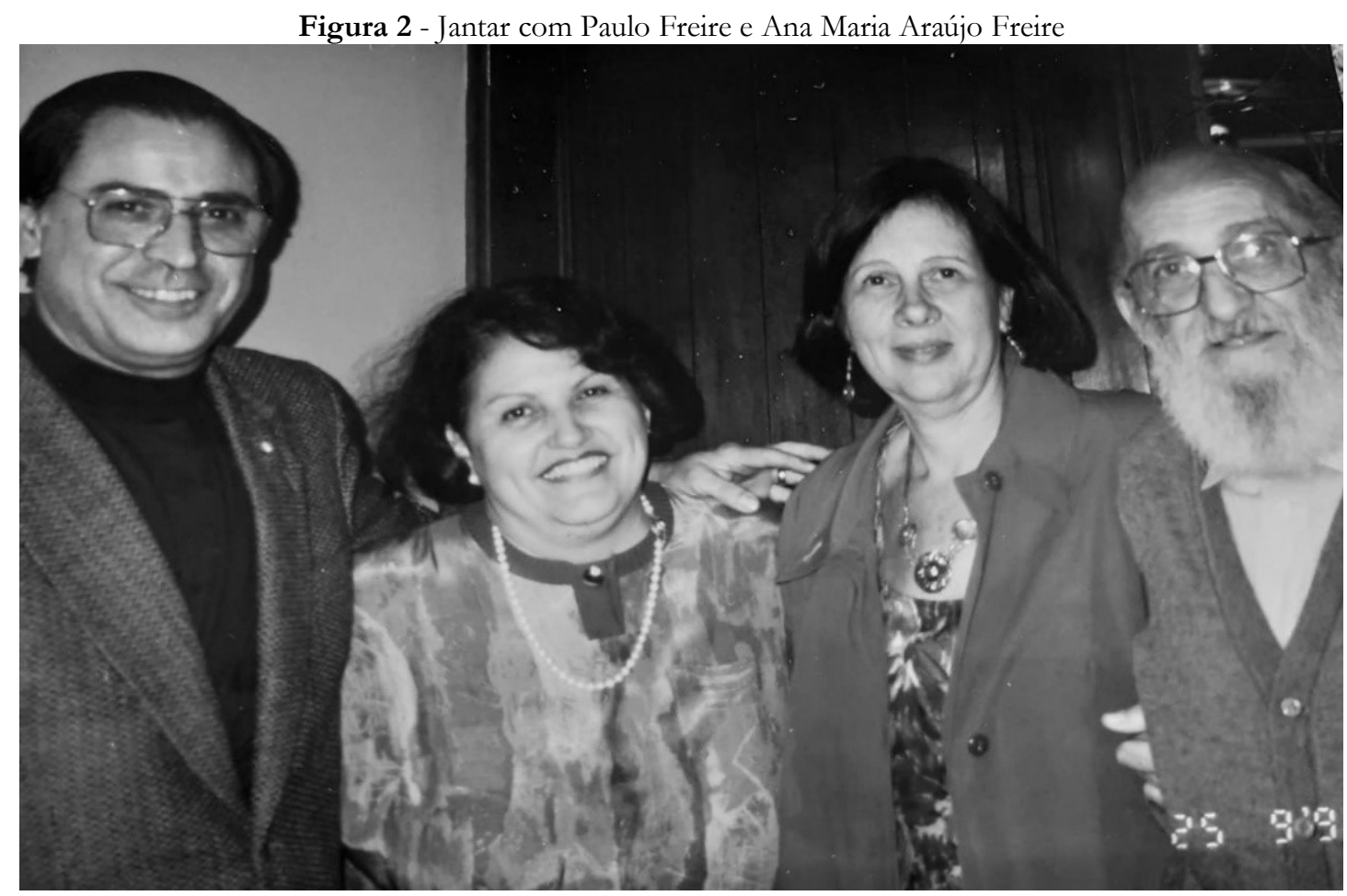

Fonte: Imagem cedida pela Professora Zélia Maria Lopes Marochi.

Obs.: À direita de Paulo Freire, encontra-se sua esposa, Ana Maria Araújo Freire, seguida pela Prof ${ }^{a}$ Zélia Maria Lopes Marochi e seu esposo, Prof. Caetano dos Santos Marochi, também professor da UEPG e anfitriões do jantar.

Éramos em torno de 50 pessoas. Enquanto aguardávamos o jantar, entre fotos, cumprimentos e toda a animação que circunda uma pessoa conhecida como Paulo Freire, houve um momento ímpar que minha memória registra com grande vivacidade. A mim foi profundamente marcante o momento em que a professora e artista Maria José Dozza Subtil, do Departamento de Métodos e Técnicas de Ensino da UEPG, tocando seu violão, entoou uma canção que fez silenciar todos(as) nós, como também Paulo Freire.

Paulo Freire, tão silencioso quanto todos(as) nós, naquele tempo-lugar, a partir da narração cantada pela professora, envolveu-nos intensamente enunciando, em sua fala - genuinamente generosa e comovente - suas ideias sobre educação, diálogo, arte e, essencialmente, sobre a esperança, sobre o amor e a vida.

Imersos em sua escuta, ficamos nós, tocados(as), fascinados(as), embevecidos(as). Com sua visão de mundo traduzida naquele dizer, Paulo Freire aproximava-nos como sujeitos de uma história passível de mudança, no momento político flamejante em que nos situávamos.

Passados vários anos do ocorrido, revi a professora e, em nossa conversa, o relembramos. A professora me fez saber que a canção se tratava de "História triste de uma praieira", composta

\footnotetext{
8 "Era o meu lindo jangadeiro/ De olhos da cor verde do mar/ Também como ele traiçoeiro/ Mentiu-me tanto o seu olhar/Ele passava o dia inteiro/Longe nas águas a pescar/ E eu intranquila, o seu veleiro/ Lá no horizonte a procurar/ Mas quando a tarde escurecia/ Um sino ouvia a repicar/ A badalar a Ave Maria/ Vi uma vela sobre o mar/ Era o meu lindo jangadeiro/ Em seu veleiro a regressar/ E à praia o seu olhar primeiro/ Buscava ansioso o meu olhar/ Quando
} 
por Adelmo Tavares e Stefânia de Macedo, em 1929, e imortalizada na interpretação de Inezita Barroso. A letra da canção conta a história de um amor não consumado, amor enganoso e triste.

Em vários momentos nas conferências que fez, Paulo Freire referiu-se ao processo de impedimento do então Presidente da República, Fernando Collor de Mello, caracterizando a conjuntura política como asfixiante, pela impunidade que se aprofundava e se generalizava. Resguardadas as proporções, acredito que tem muito em comum ao que vivemos hoje.

Os desdobramentos dos acontecimentos daquele ano de 1992 fizeram os rumos da democracia mudar em nosso país, e, por quase 30 anos, a vivemos com relativa dignidade. $\mathrm{O}$ momento presente anseia pela volta das manifestações de resistência, pois há um grito silenciado em nossas gargantas. Quiçá possamos entoá-lo logo ali no futuro, tão logo as barreiras impostas pela pandemia da Covid-19 tenham sido liberadas e tenhamos segurança para ocupar as ruas e as praças, movidos(as) pelo sonho e pela esperança, como queria Paulo Freire.

\section{Considerações finais}

Como propus, inicialmente, para a escrita deste texto, trazer o tema da esperança em algumas das obras de Paulo Freire, para relatar a experiência de tê-lo conhecido no ano de 1992, na UEPG, foi desafiador e emblemático, em razão deste momento tão específico, em que os sinais de alerta estão acionados para a banalização da vida, o desprezo à solidariedade, às intolerâncias, o desamparo de milhares, de milhões de pessoas no mundo e em nosso país, sentimentos tão caros à vida e aos escritos de Paulo Freire.

O evento ao qual me referi na última parte do texto, em que tive, juntamente a colegas da instituição, a grata satisfação de passar algumas horas na companhia de Paulo Freire; uma generosidade da vida, trouxe, sem nenhuma dúvida, um valor imprescindível em minha trajetória pessoal e profissional. As conferências feitas por Paulo Freire e por Ana Maria de Araújo Freire, nos dias que estiveram em Ponta Grossa, são, a meu juízo, momentos importantes da história da cidade e da Universidade. Assim, com este texto, espero ter contribuído para referenciar a passagem do educador em nossas cercanias.

Procurei trazer de seus escritos os argumentos de que o pessimismo faz parte da insubmissão dos esperançosos(as); logo, pensar em um futuro melhor é possível. E, como Paulo Freire anunciou em sua vasta produção intelectual, é uma tarefa urgente, um ato de resistência, uma escolha política. Como afirma Pinheiro-Machado (2019, p. 25), "[...] a esperança é uma escolha política, não apenas porque ela nos ajuda a suportar o terror autoritário, mas também porque ela nos direciona de maneira tática para o amanhã - que esperamos, será maior e melhor".

Paulo Freire exercitou uma ferrenha crítica à miséria real do mundo e ofereceu inúmeras tentativas de detê-la pela educação, colocando-se ao lado dos "esfarrapados do mundo e aos que neles se descobrem e, assim descobrindo-se, com eles sofrem, mas sobretudo com eles lutam", como escreveu na epígrafe de sua obra mais lida e mais citada nas ciências humanas no mundo: Pedagogia do oprimido, de 1974.

ditosa eu me sentia/ Passava os dias a cantar/A ver se em breve escurecia / A hora feliz do seu voltar/ Mas há na vida sempre um dia/ Dia de um sonho se acabar/ Este me veio em que não via/ O seu veleiro regressar/ Não mais voltou o seu veleiro/ Não mais o vi por sobre o mar/ O seu olhar lindo e traiçoeiro/ Não buscou mais o meu olhar/ Por uma tarde alvissareira/ O sino ouvi a repicar/ Era o meu lindo jangadeiro/ Que ia com outra se casar" (MACEDO; TAVARES, 1929, n.p.). 
Nesse sentido, neste texto, procurei, de alguma maneira, trazer, em seu registro, a importância do educador e a defesa de sua memória no cenário brasileiro atual, como criador de um pensamento pedagógico original e essencialmente democrático, por isso revolucionário.

Sua proposta metodológica, política e libertadora, considerada perigosamente subversiva pelo regime militar, e caracterizada como doutrinária nos dias atuais, posiciona a educação como espaço de transformação social e propõe a emancipação social dos sujeitos, por isso amedronta. E talvez por essa razão, tenha sido proposto, em um projeto de lei pífio, retirar do educador o título de Patrono da Educação Brasileira, proposição injusta e ofensiva à democracia, à educação e ao povo brasileiro.

Para finalizar o texto, retomo a legítima convocação de Paulo Freire à utopia, ao "inédito viável" em uma canção primorosa chamada "Samba da Utopia":

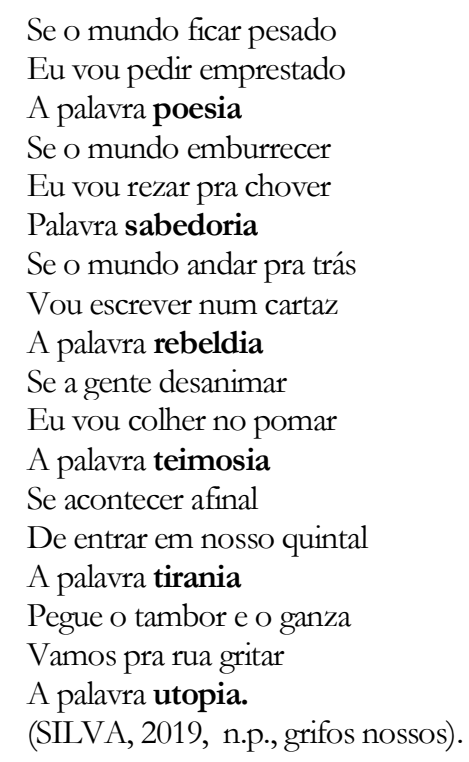

Composta às vésperas do segundo turno eleitoral em 2018, pelo cantor e compositor capixaba Jonathan Silva, em razão das ameaças e da noção de que enfrentaríamos tempos difíceis, a canção passou a ser um alento para quem não teme falar de esperança e que permanece na luta contra os discursos de ódio, de preconceito, de intolerância, de violência, que tira a "boniteza do mundo", como enfatizava o insubmisso sonhador Paulo Freire.

\section{Referências}

AMARAL, R. B. A vida quer é coragem: a trajetória de Dilma Rousseff, a primeira presidenta do Brasil. Rio de Janeiro: Sextante, 2011.

ARAÚJO, C. Paulo Freire é o antípoda de Jair Bolsonaro. Justificando, jan. 2020. Disponível em: https://www.justificando.com/2020/01/21/paulo-freire-e-o-antipoda-de-jair-bolsonaro/.

Acesso em: 16 ago. 2020.

BRANDÃO, C. R. O que é o Método Paulo Freire?. São Paulo: Brasiliense, 1981.

BRASIL. Lei $\mathbf{N}^{\mathbf{o}}$ 12.612, 13 de abril de 2012. Declara o educador Paulo Freire Patrono da Educação Brasileira. Brasília: Presidência da República, Casa Civil, Subchefia para Assuntos Jurídicos, [2012]. Disponível em: http://www.planalto.gov.br/ccivil_03/_Ato20112014/2012/Lei/L12612.htm. Acesso em: 26 abr. 2021. 
CALLADO. A. Tempo de Arraes: uma revolução sem violência. 2. ed. Rio de Janeiro: Paz e Terra, 1979.

CANCIAN, R. Governo Collor de Mello (1990-1992) - Presidente renuncia. UOL, História do Brasil, 20 dez. 2013. Disponível em: https://educacao.uol.com.br/disciplinas/historiabrasil/governo-collor-de-mello-1990-1992-presidente-renuncia.htm?cmpid=copiaecola. Acesso em: 19 ago. 2020.

CAVA, B.; COCO, G. Amanhã vai ser maior: o levante da multidão no ano que não terminou. São Paulo: Annablume, 2014.

DALTRO, M. R.; FARIA, A. A. de. Relato de experiência: Uma narrativa científica na pósmodernidade. Estudos e Pesquisas em Psicologia, Rio de Janeiro, v. 19, n. 1, p. 223-237, 2019. DOI: https://doi.org/1012957/epp.2019.4305

FERNANDES, S. Sintomas mórbidos: a encruzilhada da esquerda brasileira. São Paulo: Autonomia Literária, 2019.

FREIRE, A. M. A. Analfabetismo no Brasil: da ideologia da interdição do corpo à ideologia nacionalista, ou como deixar sem ler e escrever desde as Catarinas (Paraguaçu), Filipas, Madalenas, Anas, Genebras, Apolônias e Grácias até os Severinos. São Paulo: Cortez, 1989.

FREIRE, A. M. A. Notas explicativas. In: FREIRE, P. (org.). Pedagogia da esperança: um reencontro com a pedagogia do oprimido. 8. ed. São Paulo: Paz e Terra, 2001. p. 205-245.

FREIRE, P. Paulo Freire: “Concepções de Educação, Educação de Adultos e Educação Popular”. Ponta Grossa, 25 set. 1992a. 1 vídeo (1h44m17s). Palestra publicada pelo canal PPGE UEPG. Disponível em: https://www.youtube.com/watch?v=O-MCmak5sJA\&list=PLOLMzfnjhnaRTP47JzsrrJOSh-VpOv-j\&index =2\&t=1895s. Acesso em: 23 abr. 2021.

FREIRE, P. Paulo Freire: "Dialogando sobre a docência na Universidade". Ponta Grossa, 25 set. 1992b. 1 vídeo (2h03m57s). Palestra publicada pelo canal PPGE UEPG. Disponível em: https://www.youtube.com/watch?v=BPwbDLbDlYo\&list=PLOLM-zfnjhnaRTP47JzsrrJOShVpOv-j\&index $=1 \& \mathrm{t}=363$ s. Acesso em: 23 abr. 2021.

FREIRE, P. Canção Óbvia. In: FREIRE, P. Pedagogia da Indignação: cartas pedagógicas e outros escritos. São Paulo: UNESP, 2000a. p. 6.

FREIRE, P. Pedagogia da indignação: cartas pedagógicas e outros escritos. São Paulo: Editora UNESP, 2000b.

FREIRE, P. Pedagogia da esperança: um reencontro com a Pedagogia do oprimido. 8. ed. São Paulo: Paz e Terra, 2001.

FREIRE, P. Pedagogia do oprimido. 71. ed. Rio de Janeiro: Paz e Terra, 2019.

FREIRE. P. Pedagogia da autonomia: saberes necessários à prática educativa. 63. ed. São Paulo: Paz e Terra, 2020.

GADOTTI, M. et al. (org.). Paulo Freire: uma bioblibliografia. São Paulo: Cortez; Instituto Paulo Freire; Brasília: UNESCO, 1996. 
GIROUX, H. A. Um livro aos que cruzam fronteiras. In: GADOTTI. M. et al. (org.). Paulo Freire: uma bioblibliografia. São Paulo: Cortez; Instituto Paulo Freire; Brasília: UNESCO, 1996. p. $569-570$.

MACEDO, R. S. A pesquisa e o acontecimento: compreender situações, experiências e saberes acontecimentais. Salvador: EDUFBA, 2016.

MACEDO, S.; TAVARES, A. História triste de uma praieira. Polygram, 1929. Disponível em: https://www.letras.mus.br/stefana-de-macedo/1054065/. Acesso em: 26 abr. 2021.

PAULO Freire traça perfil educacional do país. Jornal da Manhã, Ponta Grossa, 25 de set. 1992.

PINHEIRO-MACHADO, R. O amanhã vai ser maior: que aconteceu com o Brasil e possíveis rotas de fuga para a crise atual. São Paulo: Planeta do Brasil, 2019.

SANTOS, B. S. O futuro começa agora: da pandemia à utopia. São Paulo: Boitempo, 2021.

SILVA, J. O samba da Utopia. Produção independente. São Paulo, 2019. Disponível em: https://www.letras.mus.br/ceumar/samba-da-utopia/. Acesso em: 25 abr. 2021.

SOUZA, J. A elite do atraso: Rio de Janeiro: Estação Brasil, 2019.

UEPG. Universidade Estadual de Ponta Grossa. Projeto de Extensão Redescobrindo o Mundo. Ponta Grossa: UEPG, 1989.

UEPG. Universidade Estadual de Ponta Grossa. Relatório parcial do Projeto de Extensão Redescobrindo o Mundo. Ponta Grossa: UEPG, 1994.

UEPG. Universidade Estadual de Ponta Grossa. Relatório final do Projeto de Extensão Redescobrindo o Mundo. Ponta Grossa: UEPG, 1998.

UEPG traz Paulo Freire para a Jornada de Educação de Adultos. Diário dos Campos, Ponta Grossa, 25 de set. 1992.

Recebido em 10/08/2020

Versão corrigida recebida em 19/04/2021

Aceito em 25/04/2021

Publicado online em 18/05/2021 